\title{
Marketing Provision of Transformational Economic Processes
}

\author{
Svetlana Kovalchuk \\ Department of Marketing and Trade \\ Entrepreneurship \\ Khmelnytsky National University \\ Khmelnytsky, Ukraine \\ sveta_marketing@ukr.net, \\ https://orcid.org/0000-0001-9535-8678
}

\author{
Alona Tanasiichuk \\ Department of Marketing and Advertising \\ Vinnytsia Trade and Economics Institute, \\ KNTEU \\ Vinnytsia, Ukraine \\ tanass2005@ukr.net, \\ https://orcid.org/0000-0002-7967-0239
}

\author{
Svetlana Sirenko \\ Department of Commodity Studies, Expertise \\ and Trade Business \\ Vinnytsia Trade and Economics Institute, \\ KNTEU \\ Vinnytsia, Ukraine \\ sirenko-72@ukr.net, \\ https://orcid.org/0000-0003-3083-6151
}

\author{
Yevhena Zaburmekha \\ Department of Marketing and Trade \\ Entrepreneurship \\ Khmelnytsky National University \\ Khmelnytsky, Ukraine \\ zaburmehaem@ukr.net, \\ https://orcid.org/0000-0003-2223-3887
}

Keywords: transformational economic processes, marketing, marketing concept, international marketing, globalization, marketing support.

\section{INTRODUCTION}

The development of the world economy at the turn of XXXXI centuries is characterized by a dynamic economic transformation process, the essence of which is the expansion and complication of interrelations and interdependencies between States, the formation of the global market of goods, capital, labor, information technologies, internationalization of production and capital, the intensification of competition in world commodity markets over the control of resources and information.

Now the world trend of globalization is leading and determines the features of the global market space, acquires qualitatively new features of the economic community. The result of the transformation economic processes was the intensification of the international activities of various enterprises and their penetration into new markets located throughout the world, increased competition between manufacturers globally, which has led to the awareness of the companies of the different countries the importance of marketing.

The transition to modern marketing concepts in the context of economic globalization occurs in the contact of enterprise with suppliers, intermediaries, consumers, competitors, etc. in the specific economic, legal, social and other conditions. The evolution of the concept of development of the global economy, the history of the development of international markets and transition countries at the sixth technological way affect the marketing providing of the flow of transformational economic processes at the stage of its development and reform, which causes the necessity of studying the stages of 
development of international marketing in the global and domestic economy.

\section{ANALYSIS OF THE RESEARCH AND THE PROBLEM STATEMENT}

The complexity and instability of the marketing environment in which domestic enterprises operate, the threats and challenges associated with a complex geopolitical situation, variability of situation of the world economy force entrepreneurs to seek new areas and promising directions for the development of its activities not only on national but also international markets. Experts in the field of marketing Voychak A., Golubkov E. P., Didenko N. And. Kotler F., Majar C., Moisa N., Pavlenko A., Pivovarova S., Tsygankova T., Didenko N., Skripniuk D., Fedorchenko A., Okunev O., Nikitina T., Smirnov K., Backhaus K., Voeth M., Larina Y., Khrushch N., Anisimova O. made a significant scientific contribution to the study of marketing theory for transformational economic processes, proved the necessity of studying the problems of stages of the theory of international marketing in the global and domestic economy, the transition to modern methods of marketing systems for enhancing international business activities [1-9].

It is obvious that the role of marketing in the development of world industry increases even more in times of crisis, the functions and tasks of international marketing expand, there is an urgent need to study the development of the theory of international marketing in the global and domestic economy and the application of marketing to improve transformation processes in Ukraine. The aim of the article is justification of directions of improvement of transformational economic processes in Ukraine on the basis of a study of the development of international marketing in the global economy, the addition of periodization of development international marketing in Ukraine a new, modern stages.

\section{THE RESULTS OF THE STUDY}

The dynamism of economic processes affects the process of formation of the marketing concept, which is characterized by a wide variety of forms of organization of marketing activity according to specific internal circumstances and the external environment in which the company operates. A universal formula for the organization of work and mobilization of marketing tools in the field of marketing there. There is no unified scheme for build marketing system in the conditions of transformational processes.

F. Kotler, identifies major economic processes that influence the formation of the external environment of international business: the development of means of communication, transport, tourism leads to the fact that consumers are countries of the triad (Europe, North America and Japan, which accounted for more than $85 \%$ of the world's purchasing ability with a population of about 700 million people) are fairly homogeneous market, which made the transition to the sixth technological way. Such uniformity in consumer behavior favorable for the development of «global» products, and the results of technical progress, it is advisable to implement immediately in all the markets of the triad. The delay in the release of at least one of the three markets can lead to lost opportunities entering new market in the future; development costs of individual products can be so high that their compensation is possible only during the exit of enterprises in several international markets; a large part of the production and consumption of many goods $(70-80 \%)$ is carried out in the countries of the triad.

Summarizing the results of the study it is worth noticing that the characteristics of transformational economic processes in different countries lead to the need to highlight characteristic differences between marketing and international marketing (Fig.1).

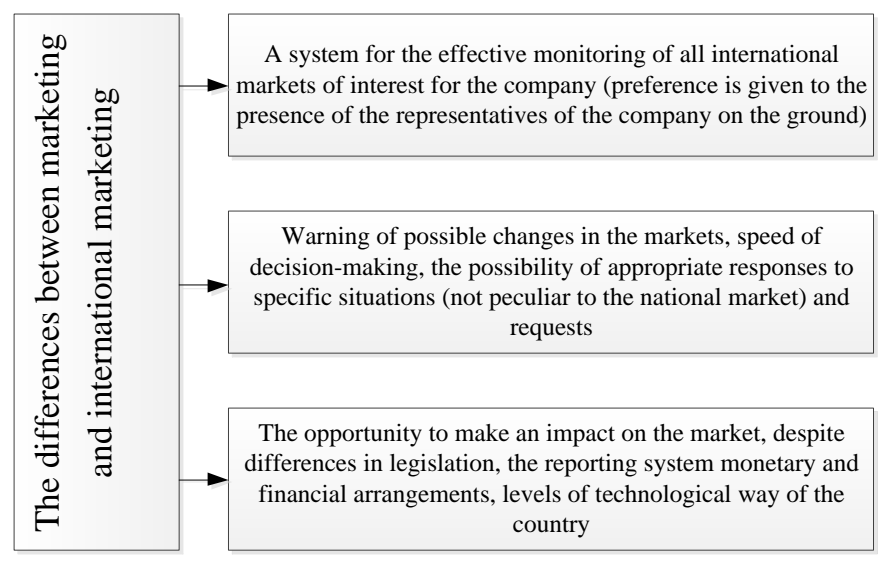

Fig. 1. Characteristic differences between marketing and international marketing in different countries

Source: own elaboration of the author

The emergence of the scientific concept of international marketing in the US connected with the practical needs of American enterprises engaged in expansion on the world market, with the development of technology internal marketing the need to improve foreign trade and foreign investments that do not meet the approaches of internal marketing.

Despite the discussed differences come to the conclusion that they are lower limit the General principles of the implementation of the marketing, while the upper boundary is the differences in country-level economic transformational flow processes influencing the process of organization of international marketing.

The formation and development of international marketing in the global economy and the transition to modern marketing concepts was carried out in various ways [6, 7] (Fig. 2).

Thanks to achieve a certain transformation of the state of the economy, business opportunities abroad, national marketing transformed into international marketing, developing according to the specifics of international markets as a separate research area. We believe that the transition from marketing to marketing enables more efficient use of marketing principles in the international markets that was implemented by most countries, which already are referred to as countries with highly developed market economies.

The development in the world of international marketing is due to the fact that the political and socio-economic conditions 
of these States are not allowed to apply a marketing for the development of national economies, at the same time, the need for the development of exports made to these countries to learn the advanced achievements of enterprises of those countries that have achieved success in the field of foreign trade, which has become an international marketing.

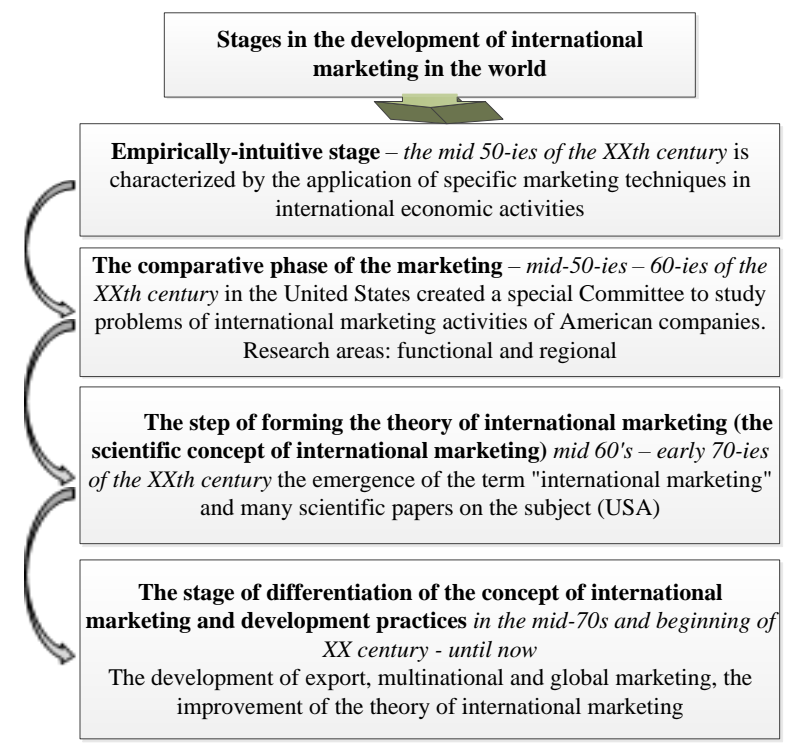

Fig. 2. The transformation of the state of development of international marketing in the global economy

Source: developed by the author based on [6, 7]

As a result, in such countries, the development of marketing as a science deals with a limited number of specialists, the marketing principles are not used in the domestic market and not receive scientific substantiation in the country. In a difficult position from the point of view of the availability of theoretical and practical base for the development of international marketing, were the CIS countries, some of which did not have sufficient experience in foreign trade operations and the required number of appropriate specialists; developing countries, which due to the peculiarities of historical development has retained its dependence on countries with developed market economies, using the experience of other, usually developed countries through the establishment of joint ventures.

Based on the analysis and synthesis stages of the transformation of economic systems in the world, developed a conceptual framework for the management of enterprises in Ukraine by means of international marketing, which is reflected in the addition of the periodization of marketing development in Ukraine the stage of «Formation of new priorities» (2000 - early 2003), which is based on the development of approaches to marketing management of an enterprise on domestic and international markets, when access to international markets and expansion of trade relations with foreign countries is dictated by the need to strengthen its own competitive position and the stage of the «Informatization of society in the modern economic process» (late 2003 - today), which is determined by the development of certain functions, in particular, communication and outsourcing, the formation of interactions with the user, in-house integration with the strengthening of backward linkages (table 1).

At the end of the twentieth century. global computer network on a planetary scale - the Internet is rapidly collects, processes quickly and almost simultaneously disseminates a very large amount of diverse information on a huge area almost uncontrollably. The information transmitted via the Internet instantly is thousands of miles, overcoming state boundaries, and provides extensive use of multimedia capabilities. For many scientists the advent of the Internet has become the basis to speak about transition of society from industrial to an information stage of development.

The rapid development of new information technologies contributed to the beginning of the fifth stage of development of the theory of international marketing «Informatization of society in the modern economic process», which came at the end of 2003, until today. In December 2003 the world summit on the information society declared the common desire to build a society based on the interests of the people, open to all, where everyone could have access to information, use it to realize its potential and create new knowledge and new information on the basis of the purposes and principles of the Charter of the United Nations. Approved by participants of the summit the draft «Declaration of principles» were defined main directions of development of world information society, among which an important role belongs to mass media, especially television and radio, which in the second half of the twentieth century. stood on the first place among the most important institutions of a democratic society and not only determined the overall level of democracy, but also directly affect its development. In turn, the newspaper and magazine and broadcasting sectors significantly affected the processes that occurred in the sphere of economy, politics, culture and the immediate influence of the power structures and political forces. A particularly important period for the development of national systems of television and radio broadcasting in post-socialist countries, for direct formation of the Ukrainian television and radio broadcasting in the process of formation of the Ukrainian state and the transformation of social relations.

Development of individual functions of international marketing, especially communication and active breeding them outside of the enterprise, the development of the scheme of interaction with the customer, internal integration with increased feedback acquired practical importance, and the strengthening of the activities of the media allowed to overcome the boundaries and distances, held the entry of Ukraine in world information space and resulted in new wave expansion to improve the system of management of the information sector, which is increasingly subordinated to commercial interests.

Despite the controversial nature of effective market transformation of economic system of Ukraine, it should be noted that the practical activity of domestic enterprises related to international marketing, much expanded tension caused by economic and socio-psychological reasons. 
TABLE I. PERIODS OF DEVELOPMENT OF MARKETING IN UKRAINE

\begin{tabular}{|c|c|c|c|}
\hline \multirow[t]{2}{*}{ Stage } & \multirow{2}{*}{$\begin{array}{l}\text { Period of } \\
\text { time }\end{array}$} & \multicolumn{2}{|l|}{ Characteristics of the stage } \\
\hline & & Practical use & The development of the science \\
\hline First & $\begin{array}{l}\text { Mid 1970s - } \\
\text { mid 1980-ies }\end{array}$ & $\begin{array}{l}\text { The fragmented stage of implementation. Use of the state foreign trade } \\
\text { associations for domestic goods in the sphere of circulation in foreign markets }\end{array}$ & $\begin{array}{l}\text { Publications on the analysis of the approaches and } \\
\text { opportunities of marketing in foreign trade activities }\end{array}$ \\
\hline Second & $\begin{array}{l}\text { Mid 1980s - } \\
\text { mid 1990s }\end{array}$ & $\begin{array}{l}\text { The situational stage of implementation. Used by all participants of foreign } \\
\text { economic activity in the sphere of circulation and production to improve the } \\
\text { competitiveness of domestic goods }\end{array}$ & $\begin{array}{l}\text { The development of international marketing for foreign } \\
\text { economic activity of enterprises, the use of theoretical } \\
\text { knowledge for the establishment and development of } \\
\text { national marketing }\end{array}$ \\
\hline Third & $\begin{array}{l}\text { The mid- } \\
1990 \mathrm{~s}-2000\end{array}$ & $\begin{array}{l}\text { The conscious stage of implementation. Used as a means of improving the } \\
\text { competitiveness of enterprises on internal and external markets. Of special } \\
\text { importance for enterprises capable of producing competitive products for export } \\
\text { markets }\end{array}$ & $\begin{array}{l}\text { The publication of textbooks, inclusion in the } \\
\text { University curriculum of the discipline «international } \\
\text { marketing», development of methodology and } \\
\text { techniques of marketing with specific companies }\end{array}$ \\
\hline Fourth & $\begin{array}{l}\text { Early } 2000- \\
\text { ies - the } \\
\text { beginning of } \\
\quad 2003\end{array}$ & $\begin{array}{l}\text { Stage of forming the new priorities. } \\
\text { The development of approaches to marketing management of the enterprise in } \\
\text { the domestic and international markets. Of particular significance for } \\
\text { companies is the application of management strategy suppliers. }\end{array}$ & $\begin{array}{l}\text { Success is guaranteed to those enterprises whose } \\
\text { activities are aimed at active use of the internal } \\
\text { capacity to change the external environment rather than } \\
\text { simply adapt to it, and their strategy focused on } \\
\text { effective marketing management. }\end{array}$ \\
\hline Fifth & $\begin{array}{l}\text { The end of } \\
2003 \text { - until } \\
\text { today }\end{array}$ & $\begin{array}{l}\text { Stage of Informatization of society in the modern economic process. The } \\
\text { industrial age - a leading role in economic development are the industrial crisis, } \\
\text { become important «long wave» of economic markets, the dynamics of which } \\
\text { are associated with the life cycles of technological structures, they have a } \\
\text { decisive effect on the character of economic dynamics. Development of } \\
\text { individual functions, especially communication and active breeding them } \\
\text { outside of the enterprise, the development of the scheme of interaction with the } \\
\text { customer, internal integration, with the strengthening of backward linkages. The } \\
\text { exponential rate of production of goods and services, natural resource } \\
\text { extraction and increased consumption of energy. } \\
\text { The development of the digital economy, it is not only the main element of } \\
\text { globalization of economy of Ukraine, but also a factor increasing the country's } \\
\text { GDP and attract new investment in the economy. }\end{array}$ & $\begin{array}{l}\text { Increased activity of the mass media, which allowed to } \\
\text { overcome the boundaries and distances, held the entry } \\
\text { of Ukraine into world information space and ushered a } \\
\text { new wave of expansion to improve the system of } \\
\text { management of the information sector, which is } \\
\text { increasingly subordinated to commercial interests. } \\
\text { Digitalization of the real economy and the basic } \\
\text { aspects of life. Investing in research and development. } \\
\text { An important moment in the transition to a digital } \\
\text { economy is to prepare next generation: online courses, } \\
\text { webinars, online conferences and online testing } \\
\text { realities in Ukraine. }\end{array}$ \\
\hline
\end{tabular}

${ }^{\text {a. }}$ Source: own elaboration of the author

Foreign trade has ceased to be a means to achieve shortterm goals, but became worthy of attention and are in dire require of experts study international experience and to further the scientific formation of marketing collateral in the period of transformation of economic processes.

\section{CONCLUSIONS}

Therefore, the proposed study of the periodization of the theory of international marketing and identify its essence and specifics in modern transformational conditions allow the conclusion that the intensification of international activities of various enterprises and their penetration to a considerable number of markets around the world, which is still significantly different from each other economic, cultural, legal and other characteristics, increased competition between manufacturers globally, has led to the realization by companies of the different countries of the importance of learning and using the theory of international marketing.

\section{ACKNOWLEDGMENT}

The author would like to thank Pavlenko A. F. of the KNEU named after Vadim Hetman for their help and support in making this work possible. This work might not have been possible had it not been for the efforts of the prior IEEEtran.
Their work still lives on to some degree within IEEEtran.

\section{REFERENCES}

[1] A. Pavlenko, and A. Vojchak Marketing. Kyiv: KNEU, 2001.

[2] Ye. Golubkov, Basics of marketing. Moscow: Fy`npress, 1999.

[3] S. Pivovarova, and L. Barkana International management. St. Petersburg: St. Petersburg. «Peter», 2000.

[4] N. Didenko, and D. Skripnyuk, International marketing: theory and analysis of specific situations. Moscow: Yurayt, 2016

[5] N. Moiseyeva, International Marketing. Moscow: Center for Economics and Marketing, 1998.

[6] T. Tsygankova, L. Petrashko, and T. Kal chenko, International trade. Kyiv: KNEU, 2001.

[7] T. Tsygankova, Modern paradigm of international marketing. Kyiv: KNEU, 2004.

[8] History of the modern world: socio-political history XV of the beginning of the XXI century. [Online]. Available: http://pidruchniki.com/1209061343512/politologiya/informatizatsiya suspilstva viznachalniy faktor suchasnogo stanu rozvitku lyudst va. accessed 29 June 2019

[9] N. Anistratenko, «International management of marketing activity in the conditions of European integration of Ukraine». Problems of the theory and methodology of accounting, control and analysis, 2 (32), pp.13-23, 2015 
[10]F. Kotler, and G. Armstrong, The basics of marketing. Moscow: Villiams, 1999.

[11]N. Didenko, and D. Skripniuk, International marketing: theory and analysis of specific situations. M.: Ywright, 2016.

[12]A. Fedorchenko, and O. Okunev, Internal marketing of the enterprise: theory, methodology, practice: monograph. Kyiv: KNEU, 2015.

[13]T. Nikitina, and K. Smirnov, Marketing at enterprises and corporations: theory and practice. Moscow: INFRA-M, 2017.

[14]K. Backhaus, and M. Voeth, Internationals Marketing. Stuttgart: Schaffer-Poeschel, 1996.

[15]Y. Larina, «Innovation and marketing strategies of enterprises on the innovative food products market», Annals of Marketing Management \& Economics, no. 1, vol. 3, pp. 33-47, 2017.

[16]N. Khrushch, «Features of functioning of virtual enterprises in the conditions of informatization of society», Herald of Khmelnytskyi National University, no 4, vol. 2, pp. 107-111, 2012.
[17]N. Moiseeva, International Marketing and Business. Moscow: COURSE: INFRA-M, 2014

[18]O. Anisimova, Adaptation of the economic mechanism of functioning of industrial enterprises in view of the international business environment. Mariupol: State Technical University «PDTU», 2012

[19]O. Kovinko, S. Kovalchuk, and I. Lisovsky, «The role of digital marketing in the activation of international business activity of enterprises», Marketing and digital technology, no. 1, pp. 55-74, 2018.

[20]O. Kovinko, and E. Lojanovich, «Information technologies in marketing». Global and national problems of economy, 2015, №6, pp. 366-368. [Online]. Available: http://global-national.in.ua/ component/content/article/14-vipusk-6-june-2015-r/1048-kovinko-om-loyanich-e-in-information-technology-in-marketing. Accessed 29 June 2019. 